\title{
Piterjiumlu Hastalarda Seruloplazmin, Albümin, İskemi-Modifiye Albümin ve Miyeloperoksidaz Düzeylerinin Belirlenmesi
}

\author{
Hanife Tuba AKÇAM 國 ${ }^{1}$, Özcan EREL [ $^{2}$
}

ÖZ

Amaç: Biyobelirteçler vücuttaki birçok hastalığın varlı̆̆ının ya da ciddiyetinin ölçülebilir bir göstergesidir. Öte yandan yapılan birçok klinik çalışmaya rağmen yaygın bir göz hastalığı olan konjonktival piterjium etiyopatojenezi tam olarak aydınlatılamamıştır. Fakat multifaktöriyel olduğu düşünülen etiyolojisinin bazı biyobelirteçlerle olan sıkı ilişkisi de iyi bilinmektedir. $\mathrm{Bu}$ çalışmada piterjium hastalığı ile serum seruloplazmin, albümin, iskemi-modifiye albümin ve miyeloperoksidaz düzeyleri arasındaki ilişkinin incelenmesi amaçlanmışıtır.

Gereç ve Yöntemler: Çalışmaya konjonktival piterjiumu olan 40 hasta ve yaş-cinsiyet uyumlu 40 sağlıklı gönüllü dâhil edildi. Tüm olgulara detaylı oftalmolojik muayene yapıldı. Ayrıca piterjium grubundaki olgularda piterjium derecelendirilmesi yapıldı. Tüm olgulardan serum örnekleri toplandı ve seruloplazmin, albümin, iskemi-modifiye albümin ve miyeloperoksidaz düzeylerine bakıldı. İstatistiksel analizde Ki-kare testi, Bağımsız örneklemler t-testi, Mann-Whitney U testi ve Spearman korelasyon analizi kullanıldı. $\mathrm{P}<0,05$ düzeyi istatistiksel olarak anlamlı kabul edildi.

Bulgular: Gruplar demografik açıdan benzerdi. Gruplar arasında seruloplazmin, albümin, iskemi-modifiye albümin ve miyeloperoksidaz düzeyleri açısından anlamlı fark saptanmadı (sırasıyla $\mathrm{P}=0,762 \quad \mathrm{P}=0,572 \quad \mathrm{P}=0,202$ ve $\mathrm{P}=0,176$ ). Piterjium grubunda korelasyon testinde albümin düzeyleri ile piterjium derecesi arasında negatif ilişki olduğu görüldü $(\mathrm{P}=0,011)$.

Sonuç: Konjonktival piterjium ile serum seruloplazmin, albümin, iskemi-modifiye albümin ve miyeloperoksidaz düzeyleri arasında istatistiksel anlamlı bir ilişki görülmemiştir. Bununla birlikte, albümin düzeyleri ile piterjium derecesi arasındaki negatif ilişki geniş hasta gruplarıyla yapılacak ileri randomize çalışmalara ihtiyaç olduğunu düşündürmektedir.

Anahtar Kelimeler: Biyobelirteçler; inflamasyon; konjonktiva; piterjium.

\section{Determination of Ceruloplasmin, Albumin, Ischemia-Modified Albumin and Myeloperoxidase Levels in Patients with Pterygium}

\begin{abstract}
Aim: Biomarkers are a measurable indicator of the presence or severity of many diseases in the body. On the other hand, despite many clinical studies, the etiopathogenesis of conjunctival pterygium which is a common eye disease has not been fully clarified. However, it is well known that the etiology, which is thought to be multifactorial, is closely related to some biomarkers. In this study, we aimed to investigate the relationship between pterygium and serum ceruloplasmin, albumin, ischemia-modified albumin and myeloperoxidase levels.

Materials and Methods: Forty patients with conjunctival pterygium and 40 age and sex-matched voluntary control subjects were included in the study. All patients underwent detailed ophthalmological examination. Pterygium was graded in pterygium group. Serum samples were obtained from all subjects and ceruloplasmin, albumin, ischemiamodified albumin and myeloperoxidase levels were determined. The statistical assessment was performed using Chisquare test, Independent samples t-test, Mann-Whitney $\mathrm{U}$ test and Spearman's correlation analysis. $\mathrm{P}<0.05$ was considered as statistically significant.
\end{abstract}

1 Düzce Üniversitesi Tıp Fakültesi, Göz Hastalıkları AD, Düzce, Türkiye

2 Ankara Yıldırım Beyazıt Üniversitesi, Tıp Fakültesi, Tıbbi Biyokimya AD, Ankara, Türkiye

Sorumlu Yazar / Corresponding Author: Hanife Tuba AKÇAM, e-mail: hanifetuba@hotmail.com

Geliş Tarihi / Received: 01.11.2019, Kabul Tarihi / Accepted: 13.12.2019 
Results: The groups were similar in terms of demographic parameters. There were no statistically significant difference between groups with regards to the level of ceruloplasmin, albumin, ischemia-modified albumin and myeloperoxidase $(\mathrm{P}=0.762 \quad \mathrm{P}=0.572$ $\mathrm{P}=0.202$ and $\mathrm{P}=0.176$ respectively). $\mathrm{A}$ negative correlation was found between albumin levels and grade of pterygium in the pterygium group $(\mathrm{P}=0.011)$.

Conclusion: No statistically significant relationship between conjunctival pterygium and serum ceruloplasmin, albumin, ischemia-modified albumin and myeloperoxidase levels was observed. However, the negative relationship between albumin levels and grade of pterygium suggests that further randomized trials with large patient groups are needed.

Keywords: Biomarkers; conjunctiva; inflammation; pterygium.

\section{GíRIŞ}

Biyobelirteçler bazı fizyolojik durumların varlığının ya da bazı hastalık durumlarının ciddiyetinin/varlığının ölçülebilir bir göstergesidir. Biyobelirteçler; sitokinler ve kemokinler (IL-1, IL1 $\beta$, IL-6, IL-8, IL-10, TNF, MIF, vb.), hücre belirteçleri (CD10, CD14, CD18, vb.), reseptörler (TNF reseptörü, toll-like reseptör, vb.), koagülasyon belirteçleri (antitrombin, aPTT, D-dimer, fibrin, vb.), vasküler endotelyal hasarı gösteren belirteçler (anjiyopoetin, laminin, neopterin, L-Selektin, vb.), vazodilatasyonu gösteren belirteçler (elastin, ACE, VIP, NO, Substans P), organ disfonksiyonunu gösteren belirteçler (ANP, endotelin-1, troponin, vb.), akut faz proteinleri (serum amiloid A protein, seruloplazmin, CRP, ferritin, alfa1-asit glikoprotein, lipopolisakkarit bağlayıcı protein, prokalsitonin, vb.) ve diğerleri (alfa-2 makroglobulin, albümin, kolesterol, elastaz, eritropoietin, HSP, laktat, laktoferrin, nükleer faktör kappa B, fibronektin, renin, bikarbonat, TGF- $\beta 1$, vb.) olarak sayabileceğimiz birçok alt gruba sahiptir (1-3). Bu belirteçlerin ortaya çıkmasındaki temel tetikleyici faktör sistemik inflamasyon oluşturabilecek herhangi bir durumdur. Bunlardan akut faz proteinleri (AFP) doku hasarına karşı vücudumuzun devreye soktuğu en önemli mekanizmalardan biridir. AFP'nin akut/kronik birçok inflamatuar süreçte önemli rol oynadığı gösterilmiştir. Bu rol artış ya da azalma şeklinde olabilir. Albümin ve seruloplazmin de AFP grubu içinde yer alır. Son yıllarda seruloplazminin endotelyal nitrik oksit sentaz (eNOS) fonksiyonunu değiştirebileceği gösterilmiş, hatta seruloplazmin ateroskleroz için yeni risk faktörlerinden biri olarak kabul edilmiştir (4). İskemi-modifiye albümin (IMA) ise iskemi sonucu oluşan reaktif oksijen türevlerinin albüminde yol açtığı değişim sonucu ortaya çıkan modifiye bir albümin türüdür. Akut koroner sendrom başta olmak üzere iskeminin erken saptanmasında kullanılan yeni bir testtir (5). Miyeloperoksidaz (MPO) ise oksidatif strese yanıt olarak lökositlerden salgılanan lizozomal bir enzimdir. MPO aktivitesinin artması nitrik oksit inaktivasyonunun artmasına, bu da nitrik oksitin vazodilatatör ve antiinflamatuar etkilerinin azalmasına neden olarak vasküler patolojiler başta olmak üzere birçok patolojik mekanizmada suçlanmıştır (6).
Piterjium kornea üzerine kontrolsüz bir şekilde uzanan anormal konjonktiva dokusu ile karakterize yaygın bir oküler yüzey hastalığıdır. Etiyopatojenezi multifaktöriyel olarak tanımlanmış olup halen aydınlatılamamış noktaları mevcuttur. Piterjiumun kökeni ile ilgili temel tartışmalar bu oluşumu hangi faktörlerin tetiklediği ve anormal hücrelerin nereden geldiği üzerinde yoğunlaşmaktadır. İleri sürülen teoriler arasında yaygın kabul gören kronik ultraviyole (UV) maruziyeti yanında oksidatif stres, inflamasyon, kalıtım, DNA hasarı ve iskemi gibi çok çeşitli mekanizmalar yer almaktadır. Son yayınlarda piterjiumun muhtemel sistemik immun-inflamatuar temeline yönelik yorumlar da sıça yer almaya başlamıştır (7-9). Bu bağlamda biz de bazı güncel serum biyobelirteçlerinin (seruloplazmin, albümin, İMA, MPO) düzeyini saptamak yoluyla piterjiumun sistemik kökenine yönelik bir çalışma yapmayı amaçladık.

\section{GEREÇ VE YÖNTEMLER}

Göz polikliniğine piterjium şikâyeti ya da takibi için başvuran hastalara standart göz muayenesi yapılıp sistemik hastalık varlığı sorguland. İzole konjonktival piterjiumu olan hastalara çalışma ile ilgili detaylı bilgi verildikten sonra gönüllü olanlar çalışmaya dâhil edildi. \%95 güven düzeyi ve \%80 güç ile her bir grup için en az örneklem genişliği 30 olarak hesaplandı. Denekler basit tesadüfi örnekleme yöntemi ile seçildi. Piterjium için cerrahi müdahale gereksinimi olan ve cerrahiyi kabul eden hastalardan ameliyat öncesi rutin ELISA işlemleri için alınan kan örnekleri işlem sonrası atılmayarak -20 santigrat derecede sakland. Kontrol grubu oluşturmak için ise basit göz kapağı kisti (zeiss kisti, moll kisti, pilar kist, epidermal inklüzyon kisti, epidermoid kist, dermoid kist, vb.) nedeniyle operasyon planlanan hastalara standart göz muayenesi yapılıp sistemik hastalık varlığ sorguland1. Basit göz kapağı kisti dışında oküler ya da sistemik hastalığı olmayan olgulara çalışma ile ilgili detaylı bilgi verildikten sonra gönüllü olanlardan ameliyat öncesi rutin ELISA işlemleri için alınan kan örnekleri işlem sonrası atılmayarak -20 santigrat derecede sakland1. Bu şekilde izole konjonktival piterjiumu olan 40 hasta (piterjium grubu, PG) ve izole basit göz kapağı kisti bulunan 40 sağlıklı gönüllü (kontrol grubu, KG) ile gruplar oluşturuldu. KG'deki olguların PG'deki olgular ile yaş-cinsiyet uyumlu olmasına dikkat edildi. Her iki gruba görme keskinliği-refraksiyon muayenesi, göz içi basınç ölçümü, biyomikroskopik inceleme ve fundus muayenesini içeren standart göz muayenesi yapıldı. PG'deki olgulara ek olarak piterjium derecelendirilmesi yapıld1. Bu derecelendirmede anormal konjonktival dokunun kornea üzerine ilerleme miktarına bakıldı. Piterjium dokusu kornea üzerine 2 milimetre (mm)'den daha az ilerlemiş ise grade 1, 2-4 mm arasında ilerlemiş ise grade 2 ve $4 \mathrm{~mm}$ 'den daha fazla ilerlemiş ise grade 3 olarak kabul edildi (10).

18 yaş altında ve 65 yaş üzerinde olanlar, gebeler (kadın olgular için), akut/kronik sistemik hastalığı olanlar, bilinen ya da tespit edilen akut/kronik göz hastalığ olanlar, göz ameliyatı geçirmiş olanlar, uzun süreli topikal/sistemik ilaç kullanım öyküsü olanlar ve sigara/alkol kullanıcıları çalışmadan dışlandı. 
Kan örneği toplama işlemi 02.09.2019-15.10.2019 tarihleri arasında Düzce Üniversitesi Göz Hastalıkları Anabilim Dalı'nda gerçekleştirildi. Saklanan kan örneklerinde 17.10.2019-18.10.2019 tarihleri arasinda Prof. Dr. Özcan Erel'in sorumluluğunda Ankara Yıldırım Beyazıt Üniversitesi Tıp Fakültesi Tıbbi Biyokimya laboratuvarında seruloplazmin, albümin, İMA ve MPO düzeylerine bakıldı.

\section{Çalışmanın Etik Yönü}

Düzce Üniversitesi Girişimsel Olmayan Çalışmalar Etik Kurulundan etik kurul izni (Karar No: 2019/178), Düzce Üniversitesi Sağlı Uygulama Araştırma Merkezi Müdürlügü̈nden ve Düzce Üniversitesi Göz Hastalıkları Anabilim Dalı Başkanlığı'ndan gerekli yasal izinler alındıktan sonra çalışmaya başlandı. Çalışmanın amacı anlatıldıktan sonra Helsinki Bildirgesi'ne bağlı kalınarak çalışmaya dâhil edilen tüm olgulardan yazılı izinleri alınd.

\section{İstatistiksel Analiz}

Verilerin istatistiksel değerlendirmesinde SPSS 22.0 (IBM Corp., Armok, NY, USA) analiz programı kullanıldı. Shapiro-Wilk testi ile değişkenlerin normal dağılıma uyup uymadığı değerlendirildi. Normal dağılıma uyan değerler ortalama \pm standart sapma (SS), normal dağılıma uymayan değerler ise ortanca (ÇAG: çeyrekler arası genişlik) şeklinde sunuldu. Niteliksel verilerin karşılaştırılmasında Ki-kare testi; niceliksel (ölçümsel) verilerin karşılaştırılmasında ise normal dağılıma uyan verilerde Bağımsız Örneklemler t testi, normal dağılıma uymayan verilerde ise Mann-Whitney U testi kullanıldı. Değişkenler arasındaki ilişkiler Spearman korelasyon testi ile incelendi. $\mathrm{p}<0,05$ düzeyi istatistiksel olarak anlamlı kabul edildi.

\section{BULGULAR}

Ortalama yaş piterjium grubunda $46,27 \pm 12,33$ y1 kontrol grubunda ise $47,18 \pm 10,61$ y1l olup, gruplar demografik açıdan benzerdi (Tablo 1).

Tablo 1. Demografik veriler ve piterjium derecesi

\begin{tabular}{|c|c|c|c|c|}
\hline \multicolumn{2}{|c|}{ Parametreler } & $\begin{array}{c}\text { Piterjium } \\
\text { Grubu } \\
(n=40)\end{array}$ & $\begin{array}{c}\text { Kontrol } \\
\text { Grubu } \\
(\mathbf{n}=\mathbf{4 0})\end{array}$ & $\begin{array}{c}\mathbf{P} \\
\text { Değeri }\end{array}$ \\
\hline \multicolumn{2}{|l|}{ 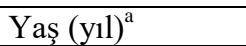 } & $46,27 \pm 12,33$ & $47,18 \pm 10,61$ & $0,803^{\mathrm{b}}$ \\
\hline \multirow{2}{*}{$\begin{array}{l}\text { Cinsiyet } \\
\text { (say1,\%) }\end{array}$} & Kadın & $22(\% 55)$ & $20(\% 50)$ & \multirow{2}{*}{$0,654^{\mathrm{c}}$} \\
\hline & Erkek & $18(\% 45)$ & $20(\% 50)$ & \\
\hline \multicolumn{2}{|c|}{ Pterjium Evresi $^{\text {d }}$} & $1(1)$ & - & - \\
\hline
\end{tabular}

${ }^{\mathrm{a}}$ : ortalama \pm standart sapma; ${ }^{\mathrm{b}}$ : Bağımsız örneklemler $\mathrm{t}$ testi; ${ }^{\mathrm{c}}$ : Ki-kare önemlilik testi; ${ }^{d}$ : ortanca (ÇAG: çeyrekler arası genişlik).

Gruplar arasında seruloplazmin, albümin, İMA ve MPO düzeyleri açısından anlamlı fark saptanmadı (Tablo 2). Piterjium grubunda korelasyon testinde seruloplazmin, IMA ve MPO düzeyleri ile piterjium derecesi arasında anlamlı ilişkiye rastlanmazken albümin düzeyleri ile piterjium derecesi arasında negatif ilişki olduğu görüldü ( $r=-0,458 \mathrm{P}=0,011$ Tablo 3).
Tablo 2. Gruplara göre seruloplazmin, albümin, iskemimodifiye albümin ve miyeloperoksidaz düzeyleri

\begin{tabular}{|l|c|c|c|}
\hline Parametreler & $\begin{array}{c}\text { Piterjium } \\
\text { Grubu } \\
(\mathbf{n}=\mathbf{4 0 )}\end{array}$ & $\begin{array}{c}\text { Kontrol } \\
\text { Grubu } \\
\text { (n=40) }\end{array}$ & $\begin{array}{c}\text { P } \\
\text { Değeri }\end{array}$ \\
\hline Seruloplazmin & $456,4 \pm 129,41$ & $446,2 \pm 126,96$ & $0,759^{\mathrm{a}}$ \\
\hline Albümin & $4,57 \pm 0,21$ & $4,54 \pm 0,17$ & $0,572^{\mathrm{a}}$ \\
\hline $\begin{array}{l}\text { İskemi-modifiye } \\
\text { albümin }\end{array}$ & $0,85(0,16)$ & $0,87(0,09)$ & $0,202^{\mathrm{b}}$ \\
\hline Miyeloperoksidaz & $78,73 \pm 31,23$ & $90,84 \pm 37,32$ & $0,176^{\mathrm{a}}$ \\
\hline
\end{tabular}

${ }^{a}$ : Bağımsız örneklemler t testi; ${ }^{b}$ : Mann-Whitney U testi.

Değerler ortalama \pm standart sapma ve ortanca (ÇAG: çeyrekler arası geniş̧lik) olarak sunulmuştur.

Tablo 3. Piterjium grubunun seruloplazmin, albümin, iskemi-modifiye albümin ve miyeloperoksidaz düzeyleri ile piterjium derecesi arasındaki ilişki

\begin{tabular}{|l|c|c|}
\hline \multirow{2}{*}{ Parametreler } & \multicolumn{2}{|c|}{ Piterjium Derecesi } \\
\cline { 2 - 3 } & $\mathbf{r}$ & $\mathbf{P}^{\mathbf{a}}$ \\
\hline Seruloplazmin & 0,029 & 0,879 \\
\hline Albümin & $-0,458$ & 0,011 \\
\hline İskemi-modifiye albümin & 0,244 & 0,194 \\
\hline Miyeloperoksidaz & 0,060 & 0,754 \\
\hline
\end{tabular}

${ }^{\mathrm{a}}$ : Spearman korelasyon testi. r: korelasyon katsayısı; P: P değeri.

\section{TARTIŞMA}

Piterjium kapak aralığına uyan bölgede anormal fibrovasküler dokunun bulber konjonktivadan kornea üzerine doğru uzanmasıdır. Patolojik olarak aslında bu yapı elastik dejenerasyon ve hiperplazi ile seyreden dejeneratif bir bozukluktur. UV 1şı̆̆ına maruziyetin nispeten yüksek olduğu bölgelerde yaygın olarak görülen piterjium esas olarak subepitelyal dokuda meydana gelen dejeneratif bir bozukluktur. Etiyolojisi hala tam olarak bilinmeyen bu hastalıkta lokal-sistemik inflamasyon, viral enfeksiyonlar, oksidatif stres, DNA metilasyonu, ekstrasellüler matriks modülatörleri, apoptotik ve onkojenik proteinler, heterozigosite kaybı, mikrosatellit instabilite, lenfanjiyogenez, kolesterol metabolizmasında değişiklikler gibi birçok faktör suçlanmaktadır (11).

Otuz iki hastadan eksize edilen primer piterjium materyalleri üzerinde yapılan bir optik koherens tomografi (OKT) çalışmasında piterjiumun OKT görüntüsü ile vimentin boyanması arasında sıkı ilişki gösterilmiştir. Bu çalışmada, OKT paternindeki anormal hiperreflektivite görüntüsünden lezyondaki kollagen dizilimi, inflamatuar hücre birikimi ve subepitelyal fibroblast hattını içeren histolojik özelliklerin sorumlu olduğu söylenmiştir (12). Başka bir immunohistokimyasal çalıșmada hastaların aynı gözünden alınan sağlam konjonktiva dokusu ve piterjium dokusunda IL-17 ve IL-23 seviyeleri incelenmiştir. Sonuçta inflamatuar hastalıklarda kilit sitokinler olarak görülen bu iki molekülün her ikisinin de piterjium dokusunda anlamlı derecede daha yüksek olduğu bulunmuştur (13).

Piterjium dokusunun laboratuvar ortamında ekimi ile geliştirilen deney modeli ile yapılan başka bir çalışmada ise mezenkimal ve hematopoietik kök hücre belirteçlerine bakılmıştır. 
$\mathrm{Bu}$ çalışmada migrasyon (CXCR4), sekretuar (MUC1, MUC4) ve oksidatif hasar (8-OHdG) belirteçlerinde yüksek, hipoksi (HIF-1 $\alpha$ ) ve proliferasyon (Ki-67) belirteçlerinde ise düşük ekspresyon gözlenmiştir. Pluripotensi (Vimentin, $\Delta \mathrm{Np} 63$ ) belirteçlerinde düşükorta, çoklu pluripotent kök hücre belirteçlerinde (Sox2, Oct4, ABCG-2) ve epitelyal hücre belirteçlerinde (CK19, CK8-18) ise zayıf ekspresyon gözlenmiştir. Büyüyen hücrelerin yüzey belirteç profiline bakıldığında ise hematopoietik belirteç CD47, mezenkimal belirteç CD90 ve CD73'de yüksek ekspresyon; IL-6 ve IL-8'de düşük ekspresyon ve hematopoietik belirteç CD34, mezenkimal belirteç CD105, progenitör belirteç CD117'de ise çok zayıf ekspresyon gözlenmiştir. Sonuçta piterjium dokusunun çok farklı hücre çeşitlerinden köken alan karışık bir yapıya sahip olduğu kanaatine varılmıştır (14). Başka bir genetik çalışmada ise iyi huylu bir hastalık olduğu bilinen piterjium doku örneklerinde $\% 44$ oranında p53 gen pozitifliği bulunmuş ve sonuçta piterjiumun bir 'doku büyüme bozukluğu' olduğu tezi öne sürülmüştür (15).

Piterjium dokusundaki vasküler yoğunluğun değerlendirildiği diğer bir çalışmada da vasküler endotelyal büyüme faktörü (VEGF) aşırı ekspresyonu ile birlikte yoğun bir anjiyogenez süreci olduğu gösterilmiştir (16).

Perra ve arkadaşlarının (17) yaptığı başka bir çalışmada piterjium doku kesitleri IgA, IgM, IgG, CD3, CD20, CD68, HLA-DR, Protein S100, HMB45 ve Melan A ile immunohistokimyasal olarak boyanmış ve sonuçta mukozal immün sistemin tüm bileşenlerinin insan piterjium dokusunda görüldüğü bulunmuştur. $\mathrm{Bu}$ sonuca göre de piterjium patojenezinde immünopatojenik mekanizmanın sorumlu olabileceği yorumunda bulunulmuştur.

Yukarıda bahsedilen çalışmalardan da anlaşılacağı üzere dokulardaki normal ya da anormal bir süreci belirten biyobelirteçler ile piterjium hastalığı arasında sıkı bir ilişki mevcuttur. Bu maddeler kanda ya da başka vücut örneklerinde saptanabilmekte ve enzim, reseptör, antikor veya peptid yapısında olabilmektedir.

Bizim çalışmamızda da akut faz proteinleri grubunda olan albümin, seruloplazmin, iskemi sonucu artan IMA ve oksidatif stres durumunda artış gösteren MPO'nun piterjium ile ilişkisi incelenmiş, fakat piterjium hastalarında çalışılan bu biyobelirteçlerde anlamlı bir değişiklik bulunamamıştır.

\section{SONUÇ}

Çalışmamızın sonuçlarına göre konjonktival piterjium hastalığı ile seruloplazmin, albümin, İMA ve MPO düzeyleri arasında istatistiksel anlamlı bir ilişki bulunamamıştır. Fakat, albümin düzeyleri ile piterjium derecesi arasında izole negatif ilişki görülmüştür. Bu bulgu her ne kadar tek başına anlamlı olarak değerlendirilemeyecek olsa da akıllarda bir soru işareti oluşmasına yol açmaktadır. Bu konuda geniş hasta popülasyonları ile yapılacak ileri randomize çalışmalara ihtiyaç vardır.

\section{KAYNAKLAR}

1. Pierrakos C, Vincent JL. Sepsis biomarkers: a review. Crit Care. 2010; 14(1): R15. doi: 10.1186/cc8872.

2. Aronson JK, Ferner RE. Biomarkers-a general review. Curr Protoc Pharmacol. 2017; 76(1): 9.23.1-9.23.17. doi: 10.1002/cpph.19.

3. Liu CH, Abrams ND, Carrick DM, Chander P, Dwyer J, Hamlet MRJ, et al. Biomarkers of chronic inflammation in disease development and prevention: challenges and opportunities. Nat Immunol. 2017; 18(11): 1175-80. doi: 10.1038/ni.3828.

4. Arenas de Larriva AP, Alonso A, Norby FL, Roetker NS, Folsom AR. Circulating ceruloplasmin, ceruloplasmin-associated genes and the incidence of venous thromboembolism in the atherosclerosis risk in communities study. J Thromb Haemost. 2019; 17(5): 818-26. doi: 10.1111/jth.14420.

5. Mishra B, Pandey S, Niraula SR, Rai BK, Karki P, Baral N, et al. Utility of ischemia modified albumin as an early marker for diagnosis of acute coronary syndrome. J Nepal Health Res Counc. 2018; 16(1): 16-21.

6. Nauseef WM. Biosynthesis of human myeloperoxidase. Arch Biochem Biophys. 2018; 642: 1-9. doi: 10.1016/j.abb.2018.02.001.

7. Malozhen SA, Trufanov SV, Krakhmaleva DA. Pterygium: etiology, pathogenesis, treatment. Vestn Oftalmol. 2017; 133(5): 76-83. doi: 10.17116/ oftalma2017133576-83.

8. John-Aryankalayil M, Dushku N, Jaworski CJ, Cox CA, Schultz G, Smith JA, et al. Microarray and protein analysis of human pterygium. Mol Vis. 2006; 12: 55-64.

9. Young AL, Cao D, Chu WK, Ng TK, Yip YWY, Jhanji V, et al. The evolving story of pterygium. Cornea. 2018; 37(Suppl 1): S55-S57. doi: 10.1097/ ICO.0000000000001744.

10. Kanski JJ. Clinical ophthalmology. A systematic approach. 6th ed. Philadelphia, PA, Pennsylvania: Butterworth- Heinemann; 2007.

11. Wanzeler ACV, Barbosa IAF, Duarte B, Borges D, Barbosa EB, Kamiji D, et al. Mechanisms and biomarker candidates in pterygium development. Arq Bras Oftalmol. 2019; 82(6): 528-36. pii: S000427492019005013105. doi:10.5935/0004-2749. 20190103.

12. Lluch S, Julio G, Pujol P, Merindano D. What biomarkers explain about pterygium OCT pattern. Graefes Arch Clin Exp Ophthalmol. 2016; 254(1): 143-8. doi: 10.1007/s00417-015-3186-9.

13. Tiong KI, Mohd Zahidin AZ, Sumugam SKA, Uchang J, Mohd Isa HD. Evaluation of interleukin-17 and interleukin-23 in pterygium: immunohistochemistry study. Asia Pac J Ophthalmol (Phila). 2017; 6(5): 403-6. doi: 10.22608/APO. 2017134.

14. Josifovska N, Szabó DJ, Nagymihály R, Veréb Z, Facskó A, Eriksen K, et al. Cultivation and characterization of pterygium as an ex vivo study model for disease and therapy. Cont Lens Anterior Eye. 2017; 40(5): 283-92. doi: 10.1016/j.clae.2017. 04.002 . 
15. Ljubojević V, Gajanin R, Amidzić L, Vujković Z. The expression and significance of p53 protein and Ki-67 protein in pterygium. Vojnosanit Pregl. 2016; 73(1): 16-20.

16. Livezeanu C, Crăiţoiu MM, Mănescu R, Mocanu C, Crăiţoiu S. Angiogenesis in the pathogenesis of pterygium. Rom J Morphol Embryol. 2011; 52(3): 837-44.

17. Perra MT, Maxia C, Zucca I, Piras F, Sirigu P. Immunohistochemical study of human pterygium. Histol Histopathol. 2002; 17(1): 139-49. doi:10.14670 /HH-17.139. 